\title{
Evaluating the Performance of Public Urban Transportation Systems in India
}

\author{
Omkarprasad S. Vaidya \\ Indian Institute of Management, Lucknow, India
}

\begin{abstract}
Evaluating the performance of public transportation systems facilitates operational improvement and strategic decisions. The purpose of this study was to evaluate the relative performance of 26 public urban transportation organizations in India using various criteria. We grouped these 19 criteria as Operations, Finance, and Accident-based. First, we evaluated the importance of these criteria groups using the Analytic Hierarchy Process $(A H P)$. Then, we evaluated the organizations (Decision Making Units, DMUs) using various criteria within each criteria group using Data Envelopment Analysis (DEA). Finally, a Transportation Efficiency Number (TEN) was developed that quantified the overall performance of the DMUs considering the 19 criteria. Included is a discussion on the applicability of this approach, thus helping practicing managers understand the lacuna, if any, and set mutual benchmarks and benefits from the experience of others. This approach helps make strategic decisions for policy-making and achieves better results.
\end{abstract}

\section{Introduction}

In India, more than 30 percent of the population lives in an urban area. Road public transport and railways are the commonly-used modes of local transportation. Hand-pulled, cycle, and auto rickshaws, taxis, and hired two-wheelers (in the state of Goa) are examples of privately-operated road public transport. Buses and specially-designed Bus Rapid Transit Systems (BRTS) are shared modes of local transportation. Various government bodies (such as the state government or municipal corporations) manage the shared mode of road transportation. In this paper, the shared mode of transportation is called a road public transportation system.

\section{Literature Review}

Evaluating the performance of a road public transport system is essential for making suitable amendments in its improvement strategy. Various studies have been carried out for evaluating performance in this area. For instance, Cruz et al. (2012) evaluated the performance of urban transportation in Portugal. To evaluate the efficiency of 52 small and 43 big cities, Data Envelopment Analysis (DEA) was used. The authors used four different 
DEA-based efficiency-benchmarking models. Holmgren (2012) conducted a stochastic frontier analysis-based study to evaluate the efficiency of public transport systems in Sweden. This analysis was based on the data collected from 1986 to 2009 to illustrate the change in efficiency over time. The reasons for development in the region were the emphasis on highly-dense routes and effective implementation of environmental and safety standards.

Yu and Fan (2009) applied a Mixed Structure Network Data Envelopment Analysis (MSNDEA) model to evaluate the performance of multimodal bus transit in Taiwan. This model represents a consumption process and was used to estimate the production efficiency, service effectiveness, and operational effectiveness of multimodal transit firms. To study the logistics strategy implemented in Guatemala and the United States, an empirical study was conducted by McGinnis et al. (2012). It appeared that the logistics managers in Guatemala were more inclined towards marketing and information strategies rather than process-driven strategies. To measure the service quality in urban bus transport, Barabino et al. (2012) applied a modified SERVQUAL model. The main purpose of the study was to develop an evaluation tool to verify the service quality standard offered. Based on the data collected during a two-week survey, various attributes were confirmed, including on-board security, bus reliability, cleanliness, and bus frequency. With a view toward understanding the areas of improvement of public transportation in Dublin, Kinsella and Caulifield (2011) conducted a survey, the results of which reflected that visitors or newcomers to a city are less concerned with the traditional aspects of public transport service quality and, instead, are more concerned with information and reliability. Another survey was conducted by Sullivan (1984), which presented some interesting observations about the performance of public surface transportation in the U.S. and Canada. The summary presents the expected developments in the economy and comments on various land use trends.

Lin (2010) developed a framework to evaluate the performance of stochastic transportation systems. The research focused on measuring the quality level of a transportation system. The author proposed a performance index to identify the probability of the upper bound of system capacity that equals a demand vector subject to budget constraints. This algorithm, based on minimal cuts, generated maximal capacity to meet demand exactly, given the budget. Then, the performance index was evaluated. Mishra et al. (2012) studied the performance indicators for public transit connectivity in multimodal transportation networks. The objective of this work was to quantify and evaluate transit services in terms of locations for funding, providing service delivery strategies, and assessing the efficiency and effectiveness. The authors illustrated their approach with an example and a network in the region of Washington-Baltimore and claimed to offer reliable indicators as a tool for determining connectivity of the multimodal transportation network. For evaluating the performance in railway, Yu and Lin (2008) proposed a DEA-based framework to estimate passenger and freight technical efficiency and service effectiveness. The authors selected 20 railways for the study and suggested various strategies for improving operational performance.

Some studies that cite exclusive application of DEA (or extensions of DEA) in the area of transportation-related decision-making are briefly presented. Hawas et al. (2012) applied 
DEA to evaluate the performance of Al Ain public bus service. The evaluation enabled an investigation of the chances of reducing operating costs given the prevailing conditions. The presented approach also helped to demonstrate improvement in performance by minor modifications in the route alignment. Hahn et al. (2013) applied a network-based DEA approach to evaluate the performance of bus companies in Seoul, Korea. The authors simultaneously used both desirable and undesirable output parameters. Several policy decisions made based on this study were the expansion of bus transit systems, additional bus stops, reduction of taxes etc.

Sanchez (2009) presented a comparative analysis of public bus transport in Spain. DEA, principal component analysis, and Tobit regression were used for this analysis. The authors showed that efficiency levels are not related to the form of ownership (public vs. private). Another finding of this study indicated six percent surplus resources. Barnum et al. (2007) developed a performance indicator (efficiency score) using DEA and Stochastic Frontier Analysis and illustrated its application to the park-and-ride lots of the Chicago Transit Authority. The authors demonstrated the suitability of the approach from a transit agency perspective to identify sub-unit inefficiencies and claim the usefulness of approach for improving both sub-unit and system performance.

Suzuki and Nijkamp (2011) presented an approach by integrating the Distance Friction Minimization model, Context-Dependent model, and Charnes, Cooper, and Rhodes (CCR) DEA methodology. This approach developed a stepwise efficiency-improving projection for conventional DEA. The authors presented an application of the proposed approach for public transport operations in Japan. Liu et al. (2013) presented a literature review on the applications of DEA. This research indicated wide application of DEA in the area of banking, health care, agriculture and farm, transportation, and education. A key feature of this paper was the development of trajectory in each application area through main path analysis. The authors also suggested that two-step contextual analysis and network DEA are the recent trends across applications.

Some works apply DEA for analyzing the performance of support systems of transportation systems. In analyzing a downtown space reservation system considering various perspectives (such as service provider, user, and the community), Zhao et al. (2011) presented two DEA-based models, radial and slacks-based. The results showed that the analysis could lead to improved designs of a downtown space reservation system. For analyzing environmental efficiency in a Chinese transportation system, Chang et al. (2013) presented a non-radial DEA model with the slacks-based measure. The results indicated that the environmental efficiency levels in most of the provinces is lower than 50 percent of the target level.

While there is sufficient existing literature to evaluate performance considering different parameters and/or a single criterion, there seems to be a need to conduct a performance study based on various criteria. In the present work, we looked at 19 criteria to evaluate the performance of the public road transportation system in India. We grouped these criteria under three categories-Operations, Finance, and Accident-based. We evaluated 26 state and/or municipal transportation systems (Decision Making Units, DMUs). Using the CCR model of DEA, we evaluated the performance of the DMUs in each category. 
This resulted in a performance number by assigning weights (importance) to the criteria groups using AHP. The analysis carried out considered the data compiled over the fiscal year ending March 2011.

This paper is organized as follows. In the next section, we briefly explain the DEA and AHP approaches. Then, we discuss the approach for the performance evaluation of various transportation systems in India. Finally, we present discussion and conclusions. Appendix 1 provides a list of DMUs, and Appendix 2 shows the various criteria within each criteria group used for evaluation.

\section{Performance Analysis Tools}

\section{Data Envelopment Analysis (DEA)}

DEA is a well-known non-parametric benchmarking tool based on linear programming. Farrell (1957) initially developed the concept of DEA, and later, Charnes, Cooper, and Rhodes (1978) developed this approach. The CCR model measures the relative efficiency of a set of firms (DMUs) that use a variety of inputs to produce a range of outputs under the assumption of constant return to scale (CRS). In DEA, the aim is to measure the performance of a DMU using the concept of efficiency or productivity, defined as the ratio of total weighted outputs to total weighted inputs. While measuring the performance, this model captures the productivity inefficiency of a firm based on its actual scale size and its inefficiency based on its actual scale (Banker 1984). The best performing unit in the set of DMUs is assigned a score of 100 percent (1), and the remaining DMUs are assigned a score ranging between 0 and 100 percent $(0$ and 1$)$ relative to the score of best-performing DMU. DEA forms a linear efficiency frontier that passes through the best-performing units within the group, and all remaining less-efficient units lie off the frontier. The term "efficiency" used in DEA is relative efficiency. The DEA formulation for $m^{\text {th }}$ DMU under consideration is as follows:

$$
\max \eta_{m}=\sum_{j=1}^{j} V_{j m} Y_{j m}
$$

Subject to:

$$
\begin{gathered}
\sum_{j=1}^{j} U_{j m} X_{j m}=1 \\
\sum_{j=1}^{j} V_{j m} Y_{j n}-\sum_{j=1}^{j} U_{j m} X_{j n} \leq 0 \\
V_{j m}, U_{i m} \geq 0 \forall i=1,2, \ldots . \text { I and } j=1,2, \ldots . J
\end{gathered}
$$

Where,

$\eta_{m}$ is the efficiency of $m^{\text {th }} \mathrm{DMU}$

$Y_{j m}$ is the $j^{t h}$ output of the $m^{\text {th }} \mathrm{DMU}$

$V_{j m}$ is the weight of $j$ th output 


$$
\begin{aligned}
& X_{i m} \text { is the } i \text { th input of the } m^{\text {th }} \mathrm{DMU} \\
& U_{i m} \text { is the weight of } i^{\text {th }} \text { input } \\
& Y_{j n} \text { and } X_{i n} \text { are the } j^{\text {th }} \text { output and } i t h \text { input of the } n^{\text {th }} \mathrm{DMU}
\end{aligned}
$$

\section{Analytic Hierarchy Process (AHP)}

Saaty (1980) initially proposed the AHP, a multi-criteria decision-making tool. AHP has a wide range of applications (Vaidya and Kumar 2006) and involves following steps:

1. Problem decomposition and hierarchy construction: Construct the overall hierarchical structure; identify the criteria.

2. Determination of alternatives: Identify the decision alternatives.

3. Pairwise comparison: Determining the relative importance of the identified criteria; the decision-maker needs to provide a score as the preferences for each pair in the hierarchy.

4. Weight calculation and consistency check: Calculate priority weights for each level using a mathematical normalization method. A consistency ratio also is calculated. The value of a consistency ratio greater than 10 percent indicates that the decisionmaker is not consistent. A review of scores is essential in such cases. In case of group decision-making, a geometric mean of scores is considered.

5. Hierarchy synthesis: Integrate the priority weights at different hierarchical levels to allow overall evaluation of alternatives, leading to a decision-making strategy. (In the present study, we conducted a single-hierarchy AHP. Therefore, this step may not be essential.)

\section{Proposed Framework}

In this section, we explain the proposed three-phase framework. Initially, using AHP, the weights of the criteria groups were determined. Then, to compute the efficiency within each criteria group, DEA was used. Finally, we computed the Transportation Efficiency Number (TEN) to reflect the overall performance of the DMUs.

\section{Phase 1}

Initially, using the AHP approach, we assigned weights to each criteria group in terms of their importance. Group decision-making involving various stakeholders such as commuters, employees, practicing managers, and members of the governing body can be useful in such situations. These values are called Criteria Importance Value (CIV). The CIV for Operations, Finance, and Accident-based group criteria were designated as (CIV)o, (CIV)f, and (CIV)a, respectively.

\section{Phase 2}

Within each criteria group, for each DMU, we computed efficiency using the CCR DEA approach. The efficiencies computed for the Operations, Finance, and Accident-based criteria groups were designated as $\eta_{o}^{i}, \eta_{f}^{i}$, and $\eta_{a}^{i}$, respectively, where $i$ is the DMU. It should be noted that the criteria within the Operations and Finance criteria groups follow a higher (output-input ratio) is better principle, i.e., benefit criteria. However, the criteria 
classified under the Accident-based group are cost attributes (lower is better). This can be considered an undesirable output. To accommodate this view, we computed the efficiencies by considering the $\left[\mathrm{TR}_{\beta}\right]$ approach presented by Ali and Seiford (1990). Here, a large, scalar $\beta$ is added to each of the undesirable output values such that the transformed values are positive. The transformation is done using the following expression:

$$
f_{r}^{j}(Q)=-q_{r}^{j}+\beta_{r}
$$

Where $r$ is the output and $j$ is the DMU.

\section{Phase 3}

For each of the DMUs, we computed TEN as the product of the efficiency and the CIV:

$$
(T E N)_{d m u}=\left(\eta_{o}(C I V)_{o}\right)+\left(\eta_{f}(C I V)_{f}\right)+\left(\eta_{a}(C I V)_{a}\right)
$$

\section{Analysis}

In the first phase of the analysis, we assigned weights to criteria groups using a group decision-making approach. A team of three-a commuter, an employee, and a practicing manager-rated the criteria using AHP. A pairwise comparison matrix was determined after considering the geometric mean of the scores of each member. The weights assigned were $0.297,0.167$, and 0.54 , respectively, for the Operations, Finance, and Accident-based criteria. Consistency ratios of the scores obtained were within limits.

In the next phase of the analysis, we computed efficiency for each DMU within each criteria group, as indicated in Phase 2 of the proposed framework.

The data required for this study were a compilation from a report by the Ministry of Road Transport and Highways, Government of India (2011) (see Table 1). DMUs for this study were various state governing bodies or cities, as shown in Appendix 1. As indicated earlier, the input and output criteria were drawn from the Operations, Finance, and Accident-based groups. Appendix 2 provides brief information about the criteria selected for the analysis. 
TABLE 1. Data for Year Ending March 2011

\begin{tabular}{|c|c|c|c|c|c|c|c|c|c|c|c|c|c|c|c|c|c|c|c|}
\hline & NA & NFA & AFH & SS & REK & TR & RE & RPB & TC & CDT & OC & SC & AFU & SP & VP & FE & PKO & PKP & PC \\
\hline Ahmedabad & 538 & 17 & 942 & 5274 & 525.1 & 10890.58 & 2074.2 & 3167.43 & 24809.47 & 4725.16 & 7215.62 & 12119.92 & 674 & 27.28 & 152.71 & 3.47 & 31700.2 & 21021 & 844.7 \\
\hline Andhrapradesh & 2879 & 1047 & 21802 & 120566 & 28958 & 521485.87 & 1800.84 & 6553.2 & 548366.97 & 1893.66 & 6891 & 236927.87 & 21701 & 65.8 & 363.9 & 5.17 & 1462379 & 973944 & 582.9 \\
\hline B.E.S.T. & 847 & 49 & 4652 & 30183 & 2615.2 & 111278.17 & 4255.1 & 6553.56 & 149416.42 & 5713.45 & 8799.66 & 78982.73 & 4082 & 23.74 & 154.02 & 2.91 & 176102 & 123071 & 904.1 \\
\hline Bangalore & 556 & 88 & 6110 & 32953 & 4580.2 & 132934.51 & 2902.37 & 5960.79 & 127899.53 & 2792.44 & 5735.02 & 45986.74 & 5641 & 38.08 & 205.38 & 4.01 & 223844.2 & 197604.2 & 699.6 \\
\hline Calcutta & 130 & 9 & 956 & 6102 & 348.6 & 6541.41 & 1876.59 & 1874.65 & 25142.74 & 7212.9 & 7205.46 & 17769.53 & 501 & 15.65 & 99.9 & 3.37 & 20173 & 12108 & 483.2 \\
\hline Chandigarh & 125 & 8 & 471 & 2136 & 439.5 & 11148.4 & 2536.78 & 6484.83 & 14905.84 & 3391.78 & 8670.47 & 6484.96 & 444 & 56.37 & 255.63 & 4.09 & 21974 & 20215.6 & 458.6 \\
\hline Delhi & 209 & 62 & 5771 & 35557 & 2920.7 & 96454.13 & 3302.43 & 4579.07 & 325108.12 & 11131.17 & 15434.19 & 95946.7 & 4330 & 22.5 & 138.66 & 4.24 & 197602.3 & 138010.9 & 525.4 \\
\hline Gujarat & 1010 & 204 & 7692 & 40670 & 9485.1 & 196804.31 & 2074.89 & 7009.75 & 212854.15 & 2244.1 & 7581.41 & 85273.6 & 6327 & 63.9 & 337.84 & 5.53 & 472465.7 & 325906.6 & 286.8 \\
\hline Haryana & 296 & 106 & 3249 & 16536 & 3797.1 & 85971 & 2264.13 & 7249.52 & 113704 & 2994.51 & 9588.11 & 53523 & 3079 & 62.91 & 320.19 & 4.78 & 189854 & 134796.3 & 352.7 \\
\hline Karnataka & 1278 & 233 & 7160 & 34019 & 8707.7 & 207868.28 & 2387.19 & 7953.94 & 201663.03 & 2315.92 & 7716.5 & 63281.65 & 6574 & 70.13 & 333.19 & 4.85 & 452798.8 & 329637.6 & 324.3 \\
\hline Kolhapur & 177 & 7 & 135 & 666 & 108.4 & 3188.43 & 2942.17 & 6470.68 & 3423.3 & 3158.9 & 6947.34 & 1373.17 & 125 & 44.58 & 219.93 & 3.58 & 4412.1 & 3019.1 & 719.8 \\
\hline Maharashtra & 3407 & 445 & 16214 & 103565 & 18973.3 & 493901 & 2603.14 & 8345.59 & 488878 & 2576.67 & 8260.71 & 194912 & 15359 & 50.19 & 320.6 & 4.94 & 879716 & 543987 & 428.8 \\
\hline Chennai & 1912 & 133 & 3414 & 23540 & 3471.5 & 91324.51 & 2630.67 & 7328.77 & 114308.52 & 3292.74 & 9173.23 & 51498.82 & 3007 & 40.4 & 278.59 & 4.39 & 249950 & 217963 & 1616.6 \\
\hline North & 90 & 13 & 783 & 3959 & 402.2 & 6524.7 & 1622.33 & 2283 & 20429.72 & 5079.75 & 7148.38 & 12451.79 & 468 & 27.83 & 140.72 & 4.21 & 20109 & 13950.9 & 201.4 \\
\hline Orissa & 47 & 5 & 333 & 938 & 321.8 & 6554.27 & 2036.56 & 5392.46 & 5836.91 & 1813.66 & 4802.26 & 1176.75 & 283 & 94 & 264.78 & 4.54 & 15126 & 10588.2 & 39.4 \\
\hline Punjab & 10 & 7 & 630 & 5997 & 331 & 8238.88 & 2489.46 & 3582.9 & 15649.82 & 4728.76 & 6805.75 & 10006.63 & 574 & 15.12 & 143.92 & 4.55 & 1042.5 & 940.9 & 513.4 \\
\hline Rajasthan & 493 & 168 & 4476 & 20486 & 5992 & 123583.76 & 2062.48 & 7564.47 & 142841.49 & 2383.87 & 8743.22 & 55846.83 & 4163 & 80.14 & 366.77 & 5.05 & 299601 & 222004.3 & 207.6 \\
\hline South & 56 & 12 & 408 & 2388 & 378.1 & 13453.01 & 3557.96 & 9033.72 & 14377.49 & 3802.46 & 9654.51 & 6806.27 & 350 & 43.38 & 253.9 & 4.05 & 18905.5 & 14916.5 & 622.7 \\
\hline Tamil Nadu & 465 & 74 & 1000 & 6592 & 2041.4 & 34413.87 & 1685.83 & 9428.46 & 47788 & 2340.99 & 13092.6 & 18743.27 & 919 & 84.84 & 559.28 & 5.03 & 76836.8 & 67286.4 & 73.8 \\
\hline Thane & 21 & 2 & 335 & 2368 & 39 & 1598.19 & 4094.77 & 1307.05 & 1815.84 & 4652.42 & 1485.05 & 851.14 & 205 & 4.52 & 31.92 & 2.68 & 2380.8 & 1961.2 & 195.5 \\
\hline Coimbtore & 971 & 213 & 3014 & 18466 & 4481.5 & 78751.86 & 1757.27 & 7158.54 & 105117.96 & 2345.61 & 9555.22 & 48287.28 & 2928 & 66.49 & 407.37 & 5.01 & 308245 & 249006.4 & 968.6 \\
\hline Kumbakonam & 1226 & 323 & 3596 & 22733 & 5917.9 & 97530.55 & 1648.07 & 7430.67 & 119678.88 & 2022.34 & 9118.11 & 52597.82 & 3352 & 71.32 & 450.87 & 5.52 & 371849.5 & 303225.7 & 900.7 \\
\hline Madurai & 1249 & 275 & 3460 & 14588 & 5414.7 & 97071.49 & 1792.75 & 7686.4 & 118260.15 & 2184.07 & 9364.17 & 51650.77 & 3312 & 101.69 & 428.75 & 5.47 & 363170.6 & 306149.1 & 973 \\
\hline Salem & 205 & 167 & 2056 & 12750 & 3550.9 & 56608.3 & 1594.2 & 7543.35 & 71366.96 & 2009.84 & 9510.02 & 31152.75 & 1973 & 76.3 & 473.17 & 5.46 & 228415.5 & 178818.3 & 928.3 \\
\hline Villupuram & 1625 & 237 & 3316 & 21546 & 5896.3 & 99202.24 & 1682.46 & 8196.23 & 116468.31 & 1975.29 & 9622.78 & 50307.31 & 3188 & 74.97 & 487.16 & 5.54 & 374356.3 & 322239.1 & 884.6 \\
\hline Uttarpradesh & 945 & 410 & 8557 & 32081 & 10286 & 202800.17 & 1971.61 & 6493.13 & 207647.58 & 2018.74 & 6648.33 & 68268.77 & 8196 & 87.84 & 329.33 & 5.3 & 514323 & 339453 & 150.6 \\
\hline
\end{tabular}

NA: Number of Accidents

NFA: Number of Fatal Accidents

AFH: $\quad$ Average Fleet Held

SS: $\quad$ Staff Strength

REK: Revenue Earnings Kilometers
TR: $\quad$ Total Revenue

RE: $\quad$ Revenue Earned Per Kilometer Traveled

RPB: Revenue per Bus

TC: $\quad$ Total Cost

OC: $\quad$ Operating Cost of Bus
CDT: Cost per Unit Distance Traveled

SC: Staff Cost

AFU: Average Fleet Utilized

SP: $\quad$ Staff Productivity

VP: Vehicle Productivity
FE: $\quad$ Fuel Efficiency

PKO: $\quad$ Passenger Kilometers Offered

PC: $\quad$ Passengers Carried

PKP: $\quad$ Passenger Kilometers Performed 
To compute efficiency values (as shown in Table 2), we used the DEA computer program DEAP 2.1, developed at the Centre for Efficiency and Productivity Analysis, University of New England, Australia (2011). Similar results can be obtained by using Excel Solver or other DEA tools such as DEA Solver. DEAP 2.1 was used because of its simplicity and ease of availability. Table 2 shows the efficiency computed (using DEA) for each DMU within each criteria group and the TEN computed using Expression 2.

TABLE 2.

Efficiency and TEN

\begin{tabular}{|l|r|r|r|r|c|}
\hline & Operations & Finance & Accident & \multicolumn{1}{c|}{ Ten } & Rank \\
\hline CIV & \multicolumn{1}{|c|}{0.295} & 0.165 & 0.54 & & \\
\hline Ahmedabad & 0.731 & 0.438 & 0.143 & 0.365 & 23 \\
\hline Andhrapradesh & 1 & 1 & 0.006 & 0.463 & 13 \\
\hline B.E.S.T. & 0.883 & 0.748 & 0.029 & 0.4 & 22 \\
\hline Bangalore & 0.929 & 1 & 0.022 & 0.451 & 15 \\
\hline Calcutta & 0.553 & 0.274 & 0.141 & 0.284 & 26 \\
\hline Chandigarh & 1 & 0.682 & 0.312 & 0.576 & 5 \\
\hline Delhi & 0.758 & 0.313 & 0.023 & 0.288 & 25 \\
\hline Gujarat & 0.887 & 0.933 & 0.017 & 0.425 & 20 \\
\hline Haryana & 0.963 & 0.747 & 0.041 & 0.429 & 19 \\
\hline Karnataka & 0.93 & 1 & 0.019 & 0.45 & 17 \\
\hline Kolhapur & 1 & 1 & 1 & 1 & 1 \\
\hline Maharashtra & 0.955 & 1 & 0.008 & 0.451 & 15 \\
\hline Chennai & 0.9 & 0.77 & 0.039 & 0.414 & 21 \\
\hline North & 0.652 & 0.374 & 0.173 & 0.347 & 24 \\
\hline Orissa & 1 & 1 & 0.712 & 0.844 & 2 \\
\hline Punjab & 0.96 & 0.528 & 0.215 & 0.486 & 8 \\
\hline Rajasthan & 0.954 & 0.896 & 0.032 & 0.447 & 18 \\
\hline South & 0.914 & 0.846 & 0.332 & 0.589 & 3 \\
\hline Tamil Nadu & 1 & 1 & 0.135 & 0.533 & 6 \\
\hline Thane & 0.686 & 1 & 0.404 & 0.586 & 4 \\
\hline Coimbtore & 1 & 0.84 & 0.045 & 0.458 & 14 \\
\hline Kumbakonam & 0.966 & 0.963 & 0.037 & 0.464 & 12 \\
\hline Madurai & 0.92 & 0.045 & 0.469 & 11 \\
\hline Salem & 1 & 0.995 & 0.066 & 0.495 & 7 \\
\hline Villupuram & 1 & 0.041 & 0.482 & 9 \\
\hline Uttarpradesh & 1 & & 0.471 & 10 \\
\hline
\end{tabular}

\section{Discussion}

Based on the efficiency scores (TEN values), we classified the DMUs as Best Performer, Better Performer, Above Average Performer, Below Average Performer, Modest Performer, or Poor Performer. As a reference to enable this classification, we considered a box plot of the TEN values. A DMU with a TEN score as an outlier on the higher side was considered a Best Performer (BeP). If the TEN score of a DMU lies in the 4th quartile 
(greater than 75th percentile), it was considered as Better Performer (BtP), whereas if it lies in 3rd quartile (50th-75th percentile), it was considered an Above Average Performer (AAP). Similarly, if the TEN score lies in 2nd quartile (25th-50th percentile), it was a Below Average Performer (BAP), and if TEN value lies in 1st quartile (less than 25 percentile), it was considered a Modest Performer (MP). A Poor performer (PP) DMU was an outlier on the lower side of the score.

In the present case, the values of Q3, median, and Q1 were 0.5045, 0.4605. and 0.4225, respectively. Table 3 shows the classification of DMUs based on their TEN scores.

TABLE 3.

\begin{tabular}{|l|l|l|l|}
\hline \multicolumn{1}{|c|}{ Status } & \multicolumn{1}{|c|}{ TEN Score Range } & \multicolumn{1}{c|}{ DMUs } & \multicolumn{1}{c|}{ Remarks } \\
\hline Best Performer & $0.844 \leq \mathrm{TEN} \leq 1$ & Kolhapur, Orissa & Outliers on higher side \\
\hline Better Performer & $0.5405 \leq \mathrm{TEN} \leq 0.843$ & $\begin{array}{l}\text { South, Thane, Chandigarh, } \\
\text { Tamil Nadu }\end{array}$ & 4th quartile \\
\hline $\begin{array}{l}\text { Above Average } \\
\text { Performer }\end{array}$ & $0.4605 \leq \mathrm{TEN}<0.5405$ & $\begin{array}{l}\text { Salem, Punjab, Villupuram, } \\
\text { Madurai, Uttarpradesh, } \\
\text { Kumbakonam, } \\
\text { Andhrapradesh }\end{array}$ & 3rd quartile \\
\hline $\begin{array}{l}\text { Below Average } \\
\text { Performer }\end{array}$ & $0.4225 \leq \mathrm{TEN}<0.4605$ & $\begin{array}{l}\text { Coimbtore, Bangalore, } \\
\text { Maharashtra, Karnataka, } \\
\text { Rajasthan, Haryana, Gujarat }\end{array}$ & 2nd quartile \\
\hline Modest Performer & $0.346 \leq \mathrm{TEN}<0.4225$ & $\begin{array}{l}\text { Chennai, B.E.S.T., } \\
\text { Ahmedabad, North }\end{array}$ & 1st quartile \\
\hline Poor Performer & $0 \leq \mathrm{TEN}<0.346$ & Delhi, Calcutta & Outliers on lower side \\
\hline
\end{tabular}

Once the overall classification was carried out, we looked at the Good Performers (GP) in each criteria group. This enabled us to set a benchmark within each criteria group. A GP has an efficiency score equal to 1 in at least one criteria group. These are indicated as follows:

- $\mathrm{GP}_{o}=\{$ Andhrapradesh, Chandigarh, Kolhapur, Orissa, Tamil Nadu, Coimbtore, Salem, Villupuram, Uttarpradesh\}

- $\mathrm{GP}_{f}=\{$ Andhrapradesh, Bangalore, Karnataka, Kolhapur, Maharashtra, Orissa, Tamil Nadu, Thane, Villupuram, Uttarpradesh\}

- $\mathrm{GP}_{a}=\{$ Kolhapur $\}$

We also looked at the Good Performers across the groups, as indicated below:

- GP $(o \cap f)=\{$ Andhrapradesh, Kolhapur, Orissa, Tamil Nadu, Villupuram, Uttarpradesh\}

- $\mathrm{GP}(f \cap a)=\{$ Kolhapur $\}$

- GP $(o \cap a)=\{$ Kolhapur $\}$

- GP $(o \cap f \cap a)=\{$ Kolhapur $\}$

- GP $(o \cup f \cup a)=$ AAndhrapradesh, Bangalore, Chandigarh, Karnataka, Kolhapur, Maharashtra, Orissa, Tamil Nadu, Thane, Coimbtore, Salem, Villupuram, Uttarpradesh\} 
These analyses identified the good DMUs in the specific criteria groups. We observed that there was only one DMU (Kolhapur) classified as a Good Performer in all three criteria groups. Kolhapur also emerged as a Best Performer in an earlier analysis. In total, there were 13 DMUs that can be classified as Good Performers since they have an efficiency score equal to 1 in at least one of the criteria groups. These DMUs may serve as a benchmark (peer) for the other DMUs.

Figure 1 shows the distribution of the Good Performers across criteria groups.

FIGURE 1.

Good Performers within and across each criteria group

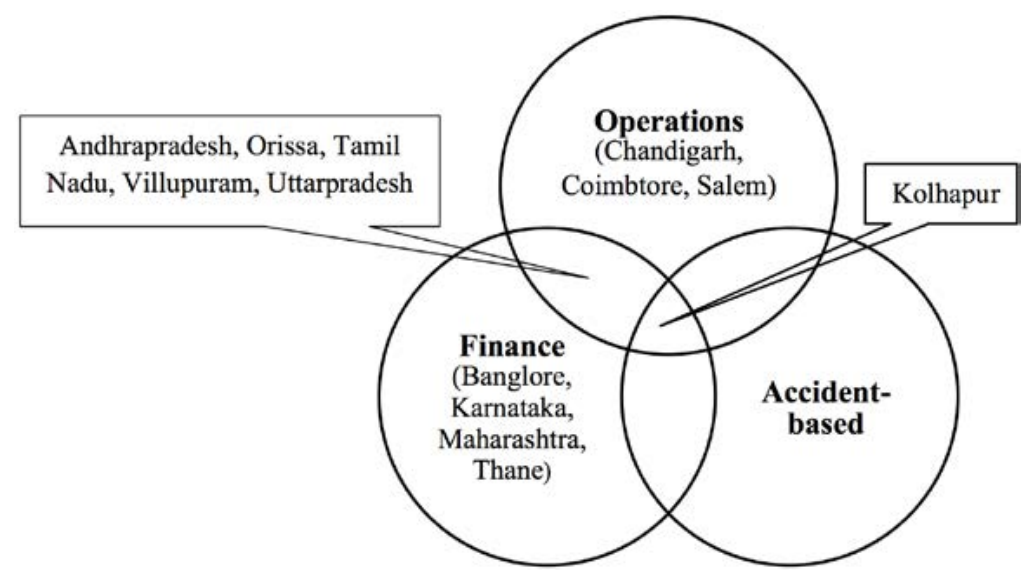

We identified the peers for the underperforming DMUs within each criteria group. The term "peers" in DEA refers to a best practice organization (or group of best practice organizations) with an efficiency score equal to 1 with which a relatively less efficient organization is compared. A peer (or a combination of peers) may provide a benchmark for relatively less-efficient organizations. Table 4 presents peers for each of the DMUs for each criteria group. 
TABLE 4. Probable Peers for Each DMU

\begin{tabular}{|c|c|c|c|c|c|c|c|c|c|c|c|c|c|}
\hline & Andhrapradesh & Bangalore & Chandigarh & Karnataka & Kolhapur & Maharashtra & Orissa & Tamil Nadu & Thane & Coimbtore & Salem & Villupuram & Uttarpradesh \\
\hline Ahmedabad & $\mathrm{O}, \mathrm{F}$ & $F$ & $\mathrm{O}$ & & $\mathrm{O}, \mathrm{A}$ & & $\mathrm{F}$ & & $\mathrm{F}$ & & & & \\
\hline Andhrapradesh & $\mathrm{O}$ & $\mathrm{F}$ & & & $\mathrm{A}$ & & & & & & & & \\
\hline Bangalore & $\mathrm{O}$ & $\mathrm{F}$ & $\mathrm{O}$ & & $\mathrm{O}, \mathrm{A}$ & & & & & & & & \\
\hline Calcutta & $\mathrm{O}, \mathrm{F}$ & $\mathrm{F}$ & $\mathrm{O}$ & & $\mathrm{A}$ & & $\mathrm{O}, \mathrm{F}$ & & $\mathrm{F}$ & & & & \\
\hline Chandigarh & & $\mathrm{F}$ & $\mathrm{O}$ & & $\mathrm{A}$ & & $\mathrm{F}$ & & $\mathrm{F}$ & & & & \\
\hline Delhi & $\mathrm{O}$ & $\mathrm{F}$ & $\mathrm{O}$ & $\mathrm{F}$ & A & & $\mathrm{O}, \mathrm{F}$ & & $\mathrm{F}$ & & & & \\
\hline Gujarat & $\mathrm{O}$ & $\mathrm{F}$ & & $\mathrm{F}$ & $\mathrm{A}$ & & $\mathrm{F}$ & $\mathrm{O}$ & & & & $\mathrm{F}$ & \\
\hline Haryana & $\mathrm{O}$ & & $\mathrm{O}$ & $\mathrm{F}$ & $\mathrm{A}$ & & $\mathrm{O}, \mathrm{F}$ & $\mathrm{O}, \mathrm{F}$ & & & & $\mathrm{F}$ & \\
\hline Karnataka & $\mathrm{O}$ & & & & $A, F$ & & $\mathrm{O}$ & $\mathrm{O}$ & & & & $\mathrm{O}$ & \\
\hline Kolhapur & & & & & $\mathrm{O}, \mathrm{A}, \mathrm{F}$ & & & & & & & & \\
\hline Maharashtra & $\mathrm{O}$ & & & & $\mathrm{A}$ & $\mathrm{F}$ & & $\mathrm{O}$ & & & & & $\mathrm{O}$ \\
\hline Chennai & $\mathrm{O}$ & $\mathrm{F}$ & & $\mathrm{F}$ & $\mathrm{O}, \mathrm{A}$ & & $\mathrm{F}$ & & & $\mathrm{O}$ & & & \\
\hline North & $\mathrm{O}$ & $\mathrm{F}$ & $\mathrm{O}$ & & $\mathrm{A}$ & & $\mathrm{O}, \mathrm{F}$ & & $\mathrm{F}$ & & & & \\
\hline Orissa & & & & & $\mathrm{A}$ & & $\mathrm{O}, \mathrm{F}$ & & & & & & \\
\hline Punjab & $\mathrm{O}$ & $\mathrm{F}$ & $\mathrm{O}$ & & A & & $\mathrm{O}, \mathrm{F}$ & & $\mathrm{F}$ & & & & \\
\hline Rajasthan & $\mathrm{O}, \mathrm{F}$ & & & $\mathrm{F}$ & $\mathrm{A}$ & & $\mathrm{F}$ & $\mathrm{O}$ & & & & $\mathrm{O}, \mathrm{F}$ & \\
\hline South & $\mathrm{O}$ & $\mathrm{F}$ & 0 & & $\mathrm{~A}$ & & $\mathrm{~F}$ & $\mathrm{O}$ & $\mathrm{F}$ & & $\mathrm{O}$ & & \\
\hline Tamil Nadu & & & & & $\mathrm{A}$ & & . & $\mathrm{O}, \mathrm{F}$ & & & & & \\
\hline Thane & & & $\mathrm{O}$ & & $\mathrm{O}, \mathrm{A}$ & & $\mathrm{O}$ & & $\mathrm{F}$ & & & & \\
\hline Coimbtore & $\mathrm{F}$ & & & $\mathrm{F}$ & $\mathrm{A}$ & & $\mathrm{F}$ & & & $\mathrm{O}$ & & $\mathrm{F}$ & \\
\hline Kumbakonam & $\mathrm{O}, \mathrm{F}$ & & & $\mathrm{F}$ & $\mathrm{A}$ & & $\mathrm{O}, \mathrm{F}$ & & & & & $\mathrm{O}, \mathrm{F}$ & \\
\hline Madurai & $\mathrm{O}$ & & & $\mathrm{F}$ & A & & $\mathrm{O}, \mathrm{F}$ & & & $\mathrm{O}$ & & $\mathrm{O}, \mathrm{F}$ & \\
\hline Salem & & & & & $\mathrm{A}$ & & & $\mathrm{F}$ & & & $\mathrm{O}, \mathrm{F}$ & & \\
\hline Villupuram & & & & & $\mathrm{A}$ & & & & & & & $\mathrm{O}, \mathrm{F}$ & \\
\hline Uttarpradesh & & & & & A & & & & & & & & $\mathrm{O}, \mathrm{F}$ \\
\hline
\end{tabular}

O: $\quad$ Peer for Operations criteria group

F: $\quad$ Peer for Finance criteria group

A: $\quad$ Peer for Accident-based criteria group 
This analysis led to identification of the benchmarks for each of the DMUs. Of note is that in the Accident-based criteria group, Kolhapur alone had an efficiency score of 1 and, thus, was the only peer to the other DMUs. Also, a DMU may have more than one peer in each criteria group. For instance, Ahmedabad could be a benchmark for Andrapradesh, Chandigarh, and Kolhapur for Operations criteria and Andrapradesh, Banglore, Orissa, and Thane for Finance criteria. Assigning of peers was carried out based on practical convenience, i.e., we assigned a peer that was common across criteria groups and with the condition that at least one peer within a criteria group was assigned. In case of a tie, a random peer was selected. With this approach, we assigned Andrapradesh (Operations and Finance criteria groups) and Kolhapur (Operations and Accident-based groups) as the peers for the Ahmeadabad DMU.

Table 5 shows the list of the peers assigned to each of the DMUs. It is obvious that if a DMU has itself as a peer, its efficiency score is maximum $(=1)$ in the criteria group under consideration.

TABLE 5.

\begin{tabular}{|c|c|c|c|}
\hline & Operations & Finance & Accident \\
\hline Ahmedabad & Andrapradesh & Andrapradesh & Kolhapur \\
\hline Andhrapradesh & Andhrapradesh & Banglore & Kolhapur \\
\hline B.E.S.T. & Kolhapur & Thane & Kolhapur \\
\hline Bangalore & Kolhapur & Bangalore & Kolhapur \\
\hline Calcutta & Orrisa & Orrisa & Kolhapur \\
\hline Chandigarh & Chandigarh & Orrisa & Kolhapur \\
\hline Delhi & Orrisa & Orrisa & Kolhapur \\
\hline Gujarat & Andrapradesh & Banglore & Kolhapur \\
\hline Haryana & Orrisa & Orrisa & Kolhapur \\
\hline Karnataka & Andrapradesh & Kolhapur & Kolhapur \\
\hline Kolhapur & Kolhapur & Kolhapur & Kolhapur \\
\hline Maharashtra & Tamil Nadu & Maharashtra & Kolhapur \\
\hline Chennai & Kolhapur & Banglore & Kolhapur \\
\hline North & Orrisa & Orrisa & Kolhapur \\
\hline Orissa & Orrisa & Orrisa & Kolhapur \\
\hline Punjab & Orrisa & Orrisa & Kolhapur \\
\hline Rajasthan & Villupurum & Villupurum & Kolhapur \\
\hline South & Andrapradesh & Banglore & Kolhapur \\
\hline Tamil Nadu & Tamil Nadu & Tamil Nadu & Kolhapur \\
\hline Thane & Kolhapur & Thane & Kolhapur \\
\hline Coimbtore & Coimbtore & Villupurum & Kolhapur \\
\hline Kumbakonam & Villupurum & Villupurum & Kolhapur \\
\hline Madurai & Villupurum & Villupurum & Kolhapur \\
\hline Salem & Villupurum & Villupurum & Kolhapur \\
\hline Villupuram & Villupurum & Villupurum & Kolhapur \\
\hline Uttarpradesh & Uttarpradesh & Uttarpradesh & Kolhapur \\
\hline
\end{tabular}


Next, we set targets by identifying the slack values and selected a slack with minimum effort, in case of multiple slack values for a DMU. We note that these slack values were indicative, and the inferences may vary as the base data are subject to change (dynamic in nature) for the next evaluation year. Practicing managers may be involved in making such decisions.

\section{Conclusions}

This study provides an approach for analyzing the performance of $26 \mathrm{DMUs}$ for 19 criteria using DEA and AHP. Usually, carrying out a performance evaluation of 26 DMUs limits the input and output criteria to approximately 9 (i.e., one-third of DMUs). We addressed this limitation by categorizing the criteria into three groups. We arrived at a performance indicator, TEN, after assigning weights (CIVs) to the groups (using AHP).

In this top-down approach of the analysis, we initially computed the overall efficiency (TEN values) for each of the DMUs. This enabled us to understand the performance of a DMU considering all 19 criteria for evaluation. To enable setting appropriate goals, we classified and ranked the DMUs based on the TEN values obtained. Then, we identified the DMUs that excelled in their criteria groups. These DMUs (Good Performers) acted as benchmarks for the other DMUs in the specific criteria group. We assigned each DMU with a peer for each criteria group to closely study, compare, and develop policies and practices. This favors healthy interaction between the DMUs. Later, the practicing manager can seek to understand the slack values. These values serve as a guideline to understand the benchmark for the next year. Further, this enables suitable and appropriate decisions to be made about improving the performance of each DMU.

Although this approach facilitates the decision-maker in understanding the performance of the DMUs and provides a benchmark, this study is not exhaustive. It provides a scope for incorporating various other criteria, such as fuel consumption, maintenance hours, level of service, punctuality, passenger travel time, on-board security, bus reliability, cleanliness, bus frequency, etc. Nevertheless, one can look at this approach as an initial stepping-stone for effectively analyzing the performance of various DMUs.

\section{Acknowledgments}

The author thanks the anonymous reviewers for their constructive suggestions. The author also thanks Professors Sushil Kumar, K. N. Singh, and R. K. Srivastava of the Indian Institute of Management, Lucknow for motivation.

\section{References}

Ali, A. I., and L. M. Seiford. 1990. Translation invariance in data envelopment analysis. Operations Research Letters, 9: 403-405.

Banker, R. D., R. F. Charnes, and W. W. Cooper. 1984. Some models for estimating technical and scale inefficiencies in data envelopment analysis. Management Science, 30: 1078-1092. 
Barabino, B., E. Deiana, and P. Tilocca. 2012. Measuring service quality in urban bus transport: A modified SERVQUAL approach. International Journal of Quality and Service Sciences, 4(3): 238-252.

Barnum, B. D, S. McNeil, and J. Hart. 2007. Comparing the efficiency of public transportation subunits using data envelopment analysis. Journal of Public Transportation, 10(2): 1-16.

Centre for Efficiency and Productivity Analysis. 2011. The University of Queensland, Australia. Accessed April, 25, 2014, http://www.uq.edu.au/economics/cepa/deap.php.

Chang, Y. T., N. Zhang, D. Danao, and N. Zhang. 2013. Environmental efficiency analysis of transportation system in China: A non-radial DEA approach. Energy Policy, 58: 277-283.

Charnes, A., W. Cooper, and E. Rhodes. 1978. Measuring the efficiency of decision-making units. European Journal of Operational Research, 2: 429-444.

Cruz, L., E. Barata, and J. Ferreira. 2012. Performance in urban public transport systems: A critical analysis of the Portuguese case. International Journal of Productivity and Performance Management, 61(7): 730-751.

Farrell, M. J. 1957. The measurement of productive efficiency. Journal of the Royal Statistical Society, 120: 253-281.

Hahn, J. S., D. K., Kim, H. C. Kim, and C. Lee. 2013. Efficiency analysis on bus companies in Seoul City using a network DEA Model. KSCE Journal of Civil Engineering, 17(6):14801488.

Hawas, Y. E., M. B. Khan, and N. Basu. 2012. Evaluating and enhancing the operational performance of public bus systems using GIS-based data envelopment analysis. Journal of Public Transportation, 15(2): 19-44.

Holmgren, J. 2013. The efficiency of public transport operations - An evaluation using stochastic frontier analysis. Research in Transportation Economics, 39(1): 50-57.

Kinsella, J., and B. Caulfield. 2011. An examination of the quality and ease of use of public transport in dublin from a newcomer's perspective. Journal of Public Transportation, 14(1): 69-81.

Lin, Y. 2010. A novel algorithm to evaluate the performance of stochastic transportation systems. Expert Systems with Applications, 37(2): 968-973.

Liu, J. S., L. Y. Y. Lu, W. M. Lu, and B. J. Lin. Y.2013. A survey of DEA applications. Omega, 41(5): 893-902.

McGinnis, M. A., J. E. Spillan, and N. Virzi. 2012. An empirical study comparing Guatemalan and United States logistics strategies. International Journal of Logistics Management, 23(1): 77-95.

Ministry of Road Transport and Highways. 2011. Review of the performance of state road transport undertakings. Accessed April, 25, 2014, morth.nic.in/writereaddata/mainlinkFile/File775.pdf. 
Mishra, S., T. F. Welch, and M. K. Jha 2012. Performance indicators for public transit connectivity in multi-modal transportation networks. Transportation Research Part A: Policy and Practice, 46 (7): 1066-1085.

Saaty, T.L. 1980. The Analytic Hierarchy Process. McGraw-Hill. New York.

Sanchez, I. M. G. 2009. Technical and scale efficiency in Spanish urban transport: Estimating with data envelopment analysis. Advances in Operations Research, 1-15.

Sullivan, B. E. 1984. Some observations on the present and future performance of surface public transportation in the United States and Canada. Transportation Research Part A: General, 18(2): 111-123.

Suzuki, S., and P. Nijkamp. 2011. A stepwise-projection data envelopment analysis for public transport operations in Japan. Letters in Spatial and Resource Sciences, 4(2):139-156.

Vaidya, O. S., and S. Kumar. 2006. Analytic hierarchy process: An overview of applications. European Journal of Operational Research, 169 (1): 1-29.

$\mathrm{Yu}$, M., and C. Fan. 2009. Measuring the performance of multimode bus transit: A mixed structure network DEA model. Transportation Research Part E: Logistics and Transportation Review, 45(3): 501-515.

Yu, M., and E. T. J. Lin. 2008. Efficiency and effectiveness in railway performance using a multi-activity network DEA model. Omega, 36(6): 1005-1017.

Zhao, Y., K. Triantis, P. M. Tuite, and P. Edara. 2011. Performance measurement of a transportation network with a downtown space reservation system: A network-DEA approach. Transportation Research Part E, 47 (6): 1140-1159. 


\section{Appendix 1 \\ DMUs and Their Weblinks}

\begin{tabular}{|c|c|c|c|}
\hline Code & Urban Transportation Unit & Web Link & City/State Web Link \\
\hline Ahmedabad & Ahmedabad Municipal Transp. Svcs. & http://www.amts.co.in/ & http://www.egovamc.com/ \\
\hline Andhrapradesh & Andrapradesh State Road Transport Corp. & http://www.apsrtconline.in/ & http://www.aponline.gov.in/ \\
\hline Bangalore & Banglore Metropolitan Transport Corp. & http://www.mybmtc.com/ & https://www.bangaloreone.gov.in \\
\hline Calcutta & South Bengal State Transport Corp. & http://sbstc.co.in/ & https://www.kmcgov.in \\
\hline Chandigarh & State Transport Authority Chandigarh & http://chdtransport.gov.in/ & http://chandigarh.gov.in/ \\
\hline Delhi & Delhi Transport Corp. & http://delhi.gov.in/wps/wcm/connect/DOIT_DTC/dtc/home/ & http://delhi.gov.in/ \\
\hline Gujarat & Gujrat State Road Transp. corp. & http://www.gsrtc.in/ & http://www.gujaratindia.com/ \\
\hline Haryana & Transport Dept., Haryana & http://hartrans.gov.in/ & http://haryana.gov.in/ \\
\hline Karnataka & Karnataka State Road Transp. Corp. & http://www.ksrtc.in/ & http://www.karnataka.gov.in/ \\
\hline Kolhapur & Kolhapur Municipal Transport & http://www.kolhapurcorporation.gov.in/ & http://kolhapur.nic.in/ \\
\hline Maharashtra & Mahararshtra State Road Transport Corp. & http://www.msrtc.gov.in/ & https://www.maharashtra.gov.in \\
\hline North & North Bengal State Transport Corp. & http://nbstc.co.in/ & http://www.wb.gov.in/ \\
\hline Orissa & Orissa State Road Transport Corp. & www.osrtc.in/ & http://www.odisha.gov.in/ \\
\hline Punjab & Punjab Road Transport Corp. & http://www.pepsurtc.gov.in/ & http://www.punjabgovt.gov.in/ \\
\hline Rajasthan & Rajasthan State Road Transport Corp. & http://rsrtc.rajasthan.gov.in/ & http://www.rajasthan.gov.in/ \\
\hline South & South Bengal State Transport Corp. & http://sbstc.co.in/ & http://www.wb.gov.in/ \\
\hline Tamil Nadu & Tamil Nadu State Transport Corp. & http://www.tnstc.in/ & http://www.tn.gov.in/ \\
\hline Thane & Thane Municipal Transport & http://thanecity.gov.in/department_details.php?id=34 & http://www.thanecity.gov.in/ \\
\hline Coimbtore & Tamil Nadu State Transport Corp. (Coimbtore Div.) & http://www.tnstc.in/ & https://www.ccmc.gov.in \\
\hline Kumbakonam & Tamil Nadu State Transport Corp. (Kumbakanom Div.) & http://www.tnstc.in/ & http://municipality.tn.gov.in/kumbakonam/ \\
\hline Madurai & Tamil Nadu State Transport Corp. (Madurai Div.) & http://www.tnstc.in/ & http://www.madurai.tn.nic.in/ \\
\hline Salem & Tamil Nadu State Transport Corp. (Salem Div.) & http://www.tnstc.in/ & http://www.salem.tn.nic.in/ \\
\hline Villupuram & Tamil Nadu State Transport Corp. (Villupuram Div.) & http://www.tnstc.in/ & http://viluppuram.nic.in/ \\
\hline Uttarpradesh & Uttarprasdesh State Road Transport Corp. & http://www.upsrtc.com/ & http://upgov.nic.in/ \\
\hline
\end{tabular}




\section{Appendix 2}

\section{Criteria for Evaluation}

The criteria considered for the analysis are grouped into three categories: Operations, Finance, and Accident-based criteria. In DEA, we classified the criteria as an input criterion and an output criterion.

\section{Criteria under Operations Group}

\section{Input Criteria:}

- Average Fleet Held (AFH): Average fleet (vehicles held) in the year. This value is slightly less than the actual fleet of vehicles held because on the road, due to maintenance and other activities, it was not possible to maintain a constant fleet throughout the year.

- Staff Strength (SS): Average work force available during the entire year.

\section{Output Criteria:}

- Average Fleet Utilized (AFU): Average fleet (vehicles) that were utilized in the year. At times, it was seen that some of the vehicles were idle in the depots and unused due to various reasons.

- Staff Productivity (SP): Measured as the average distance traveled by staff along with the vehicle, quantified as kilometers per staff per day.

- Vehicle Productivity (VP): Average distance traveled by the vehicle, quantified as kilometers per bus per day.

- Fuel Efficiency (FE): Average distance in kilometers covered by a vehicle per liter consumption of fuel (in this case, diesel).

- Passenger Kilometer Offered (PKO): Average distance of all the routes covered times number of trips offered over the entire year.

- Passenger Kilometers Performed (PKP): Average distance of all routes covered times the number of trips actually conducted over the entire year.

- Passengers Carried (PC): Average number of passengers traveled per day in a bus, quantified as passengers per bus per day.

\section{Criteria under Finance Group}

\section{Input Criteria}

- Total Cost (TC): Total cost of the facilities offered by government, quantified in lakh Indian Rupees.

- Cost per Unit Distance Traveled (CDT): Average cost incurred by government/ organizing body per kilometer distance traveled by the vehicle (given in Indian Paise; 1 Rupee $=100$ paise)

- Operating Cost of Bus (OC): Average operating cost of a bus per day, in Indian Rupees.

- Staff Cost (SC): Total money spent on staff in a year, including wages and allowances, in Indian Rupees. 


\section{Output Criteria}

- Total Revenue (TR): Revenue earnings in the year, in lakh Rupees.

- Revenue Earned per Kilometer Traveled (RE): Amount of revenue earned per kilometer traveled, in Paise.

- Revenue per Bus (RPB): Average of revenue collected by a bus per day, in Rupees.

- Revenue Earnings Kilometers (REK): Average revenue earned with respect to distance traveled by vehicles, in kilometer, in lakh Rupees.

\section{Criteria under Accident-based Group}

\section{Input Criteria:}

- Average Fleet Held (AFH): Average fleet (vehicles held) in the year; due to maintenance and other activities, it was not possible to maintain a constant fleet throughout the year.

- Staff Strength (SS): Average work force available during the entire year.

\section{Output Criteria:}

- Number of Accidents (NA): Total number accidents during entire year; includes minor accidents.

- Number of Fatal Accidents (NFA): Total number of accidents where there was substantial loss to property or humanity.

\section{About the Author}

OMKARPRASAd S. VAIDYA (vomkarin@yahoo.co.in, osv@iiml.ac.in) is an Assistant Professor in the Operations Management group at Indian Institute of Management (IIM), Lucknow, India. He obtained his doctoral degree from the National Institute of Industrial Engineering in Mumbai. His research articles have appeared in journals of international repute, including European Journal of Operational Research, International Journal of Quality and Reliability Management, International Journal of Performance and Productivity Management, International Journal of Reliability and Safety, and others. He has written cases published with IVEY (also available on the Harvard Business cases portal) and completed consultancy assignments for Indian companies. His teaching interests include service operations, quality and six sigma, and supply chain modeling. 